\title{
Comparative Evaluation of The Efficacy Of Rotary file system (Kedo-S) Vs Hand K-Files In Root Canal Preparation Of Primary Teeth Using Cone Beam Computed Tomography (CBCT) - An In Vitro Study
}

Avaliação Comparativa da Eficácia dos Sistemas de Limas Rotatórias (Kedo-S) Versus Limas manuais (Kerr) no Preparo do Canais Radiculares de Dentes decíduos Utilizando Tomografia Computadorizada de Feixe Cônico (TCFC) - Um Estudo In Vitro

Abhinaya SRINIVAS ${ }^{1}$, Ganesh JEEVANANDAN ${ }^{1}$, Lavanya GOVINDARAJU ${ }^{1}$, Erulappan Muthu Ganapathi SUBRAMANIAN ${ }^{1}$

1 - Department of Pediatric and Preventive Dentistry - Saveetha Institute of Medical and Technical Sciences - Chennai - Tamil Nadu - India.

\begin{abstract}
Objective: To evaluate the efficacy of rotary Kedo-S and hand K-files in shaping ability in primary canines using cone beam computed tomography. Material and Methods: Thirty extracted primary maxillary and mandibular canines were selected. Using cone beam computed tomography the teeth were scanned before instrumentation. In Group I, the teeth were prepared using stainless steel $\mathrm{K}$ file up to the size of 40. In the Group II teeth, U1 size Kedo-S rotary file was used in crown down technique. The instrumented teeth were scanned again with cone beam computed tomography and the images were compared. Results: The canal taper was more conical for rotary Kedo-S files as compared to K-files, which was statistically significant. Conclusion: Canal preparation with Rotary files resulted in more conical canals when compared to manual instrumentation in primary teeth that contributes to more uniform obturation.
\end{abstract}

\section{KEYWORDS}

CBCT; Hand K-fi les; Kedo-S fi le system; Primary teeth; Pulpectomy; Rotary instrumentation.

\section{RESUMO}

Objetivo: Avaliar a eficácia da instrumentação rotatória com limas Kedo-S e instrumentação manual com limas Kerr na modelagem de caninos decíduos utilizando tomografia computadorizada de feixe cônico (TCFC). Material e Métodos: Foram selecionados 30 caninos decíduos superiores e inferiores extraídos. Usando a TCFC, os dentes foram escaneados previamente a instrumentação. No Grupo I, os dentes foram confeccionados com limas de aço inoxidável até o tamanho 40. Nos dentes do Grupo II, utilizou-se a lima rotatória Kedo-S tamanho U1 na técnica coroaápice. Os dentes instrumentados foram novamente escaneados por TCFC e as imagens foram comparadas. Resultados: A conicidade do canal foi maior no grupo com instrumentação rotatória em comparação com a instrumentação manual, com diferença estatística significante entre eles. Conclusão: O preparo do canal com o Rotary resulta em canais mais cônicos em comparação com a instrumentação manual em dentes decíduos, o que contribui para uma obturação mais uniforme.

\section{PALAVRAS-CHAVE}

CBCT; Limas manuais Kerr; Sistema de limas Kedo-S; Dentes decíduos; Pulpectomia; Instrumentação rotatória. 


\section{INTRODUCTION}

$\mathrm{P}$ ulpectomy is the treatment involving eradication of infected pulpal tissue in primary teeth thus preserving the integrity of dental tissues until it is naturally shed. [1] The pulpectomy technique should be fast and simple thereby enhancing the patient cooperation and reducing the operator fatigue. According to the American Academy of Pediatric Dentistry (AAPD 2014), a pulpectomy is indicated in a primary tooth with irreversible pulpitis or necrosis or a tooth planned for pulpotomy in which the radicular pulp exhibits clinical signs of irreversible pulpitis. [2].

Root canal preparation in primary teeth is usually performed with conventional hand files. Manual preparation techniques are time consuming and can lead to iatrogenic errors. [3] In the recent times, attention has been drawn towards root canal preparation technique with Ni-Ti rotary instruments.

Barr et al first performed mechanical preparation of primary teeth using Ni-Ti rotary file system in 2000. [4] It was concluded that the use of $\mathrm{Ni}-\mathrm{Ti}$ rotary files for root canal preparation in primary teeth was faster, cost effective and resulted in consistently uniform and predictable fillings. The design and flexibility of Ni-Ti alloy instruments allow files to preserve the original anatomy of curved canals and reduce procedural errors in primary teeth. In addition to that, it results in funnelshaped canal preparation thereby producing a more predictable uniform obturation. [5] However, the existing rotary file systems have been designed for use in permanent teeth and hence modification in the sequence of using rotary files in primary teeth was advocated.

A recent survey conducted among the Indian dentists have shown that the practitioners prefer using an exclusive pediatric rotary file with modifications in the length and taper of the file for providing a better and comfortable treatment for the child. [6] An exclusive pediatric rotary file with modified length and taper introduced for canal preparation in primary teeth is the Kedo-s rotary file system (Reeganz dental care Pvt.Ltd.India). It consists of three NiTi files namely D1, E1 and U1 with the tip diameter of $0.25 \mathrm{~mm}, 0.30 \mathrm{~mm}$ and $0.40 \mathrm{~mm}$ respectively and has a variably variable [VV] taper.

D1 and E1 are designed for the preparation of the mesial and distal root canals of the primary molars, whereas $\mathrm{U} 1$ is intended for preparation of the root canals of primary anterior teeth. The working length of the files is set at $12 \mathrm{~mm}$ for the ease of insertion, removal and instrumentation of the primary root canals. Also, it has a variably variable taper corresponding to the morphology of the primary root canals. [7]

Unpredictable physiological root resorption, unknown effects of the canal instrumentation and the obturation material on the succedaneous tooth, bizarre anatomic variations and behavior management of the young children persists as the potential barriers for the pulpectomy procedure. [8] Hence, evaluating the shaping efficiency of any new instrument is mandatory to support its use in pediatric practice, thereby to predict a uniform obturation. There are no studies in the literature evaluating the shaping ability of the newly released Kedo-s rotary file system.

The aim of the present study, therefore, was to comparatively evaluate the efficacy of Kedo-s rotary files in shaping of the primary root canals.

\section{MATERIAL AND METHOD}

The study was conducted in the Department of Pediatric and Preventive Dentistry in an institution in India.

\section{Ethical Approval:}

Ethical committee approval was obtained from the Institutional Review Board prior to the start of the study. 


\section{Selection of teeth:}

Human primary maxillary and mandibular canine teeth extracted either due to orthodontic treatment or those that have been over retained beyond the age of exfoliation with root length of $10 \mathrm{~mm}$ were collected for the study. Teeth which have undergone pulpectomy, teeth with internal or extensive pathological root resorption were excluded from the study.

\section{Storage of the selected teeth:}

The teeth selected for the inclusion into the study were washed under running water and stored in sterile water until the experimental time.

\section{Sample size calculation:}

The sample size was calculated from a previously published study at $85 \%$ power using SPSS Software (11.5, SPSS Inc., Chicago, IL, USA) and arrived to the sample size of thirty. The selected teeth were randomly allotted to one of the two groups of 15 teeth each.

\section{Preparation of study specimens:}

Pre-operative images of all the included teeth were taken using cone beam computerized tomography (CBCT) and the width of root canal taper at the cervical, middle and apical third were measured as shown in figure 1 . The measurements of the cervical, middle and apical third were standardized for all tooth specimens. The standardizations are as follows: root canal taper at the apical third was measured as $3 \mathrm{~mm}$ from the apex, taper at middle third was measured at $6 \mathrm{~mm}$ from the apex and at $8 \mathrm{~mm}$ from the apex for the taper of the coronal third of the root canal.

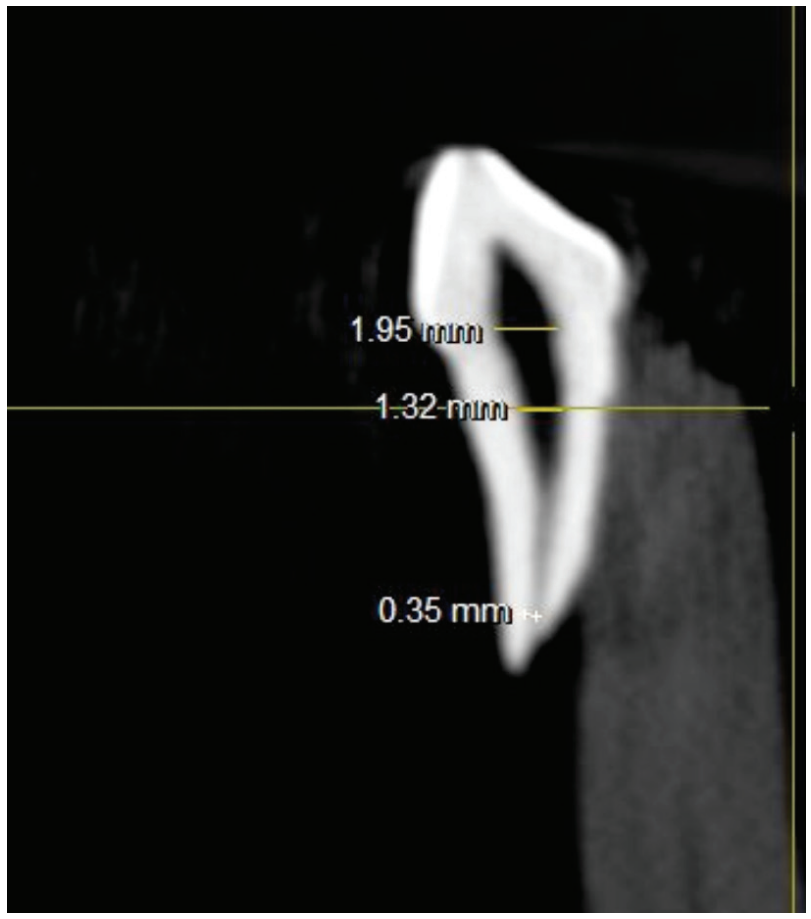

Figure 1 - showing pre-operative CBCT image of primary canine with measurements of cervical, middle and apical third of the root canal.

A single investigator prepared all the selected teeth. No.6 round bur (Mani) was used in a high speed hand piece to remove the superficial caries and the endodontic access opening was prepared using No.330 pear shaped bur (Mani). No.10 size K file (Mani) was used to determine the patency of the canals. The working length was kept $1 \mathrm{~mm}$ short of the apical foramen.

Group 1(N=15): The root canals were manually prepared using $21 \mathrm{~mm}$ stainless steel K-files (Mani) from size 15-40 in quarter pull turn technique.

Group 2(N=15): The root canals were instrumented with Rotary file system (Kedo-S file system; Reeganz dental care Pvt. Ltd. India). U1 Kedo-S rotary file was used in crown down technique with $\mathrm{X}$ - Smart motor (Dentsply India Pvt. Ltd., Delhi, India) at 300 rpm and $2.2 \mathrm{~N} \mathrm{~cm}$ torque. 
Irrigation solution was standardized to $10 \mathrm{ml}$ of $1 \%$ sodium hypochlorite followed by saline in both groups after each file use during the entire cleaning and shaping procedure. Also, the files of both groups were lubricated with EDTA gel (RC help; Prime dental products Pvt. Ltd. India) every time as they were used for the biomechanical preparation All the procedures for both the groups were done by a single operator. All measures possible was taken into consideration to standardize the parameters between the two groups to overcome any sort of bias.

\section{Assessment of shaping ability:}

Cone beam computed tomography (CBCT) was used to analyze the internal three-dimensional root canal shapes after preparation. The root canal taper was measured at the cervical, middle and apical third of the root canal as shown in figure 2 .

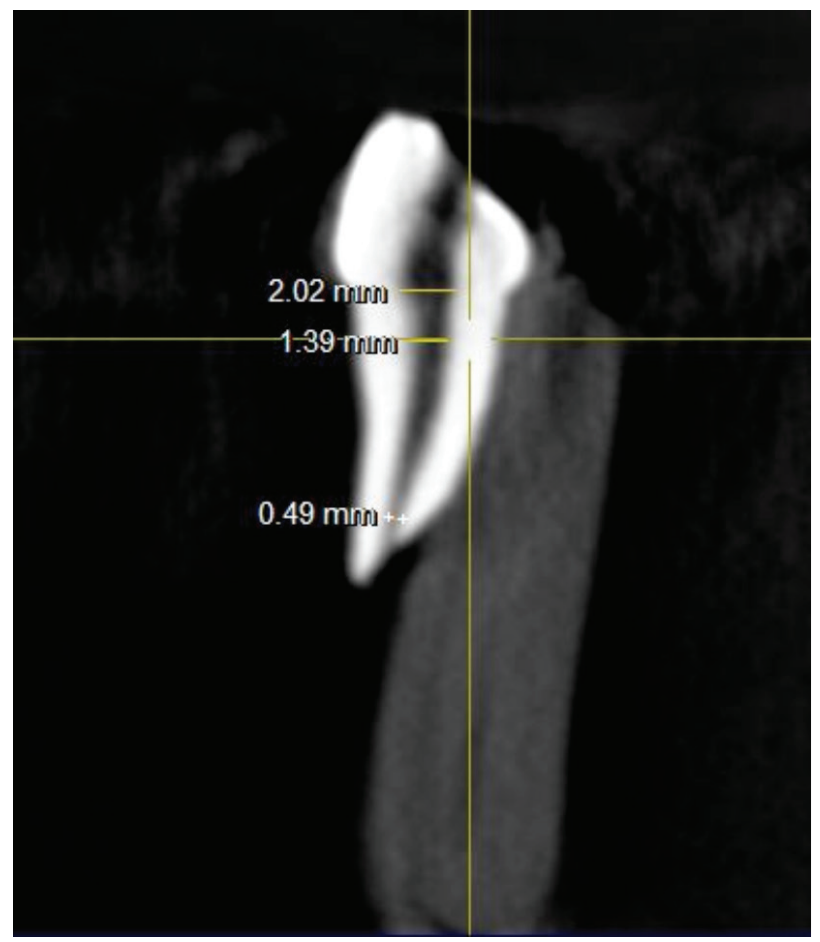

Figure 2 - showing post-operative CBCT image of primary canine with measurements of cervical, middle and apical third of the root canal.
Statistical analysis: The collected data were analyzed with IBM.SPSS statistics software 23.0 Version. To describe about the data, descriptive statistics, mean and standard deviation were used. To find the significant difference between the bivariate samples in the independent groups, the unpaired t-test was used. In the above statistical tool, the probability value 0.05 is considered as significant level.

Table 1 - Depicts the overall comparison of shaping efficacy between both the groups of the root canal taper in the coronal third, middle third and apical third after measuring using CBCT pre-operatively and post operatively respectively. From the obtained results, it is observed that with Kedo-s rotary file, the canal taper was significantly more than the hand files

\begin{tabular}{|cccccc}
\hline GROUPS & N & $\begin{array}{c}\text { MEAN } \\
\text { (PRE-OP) }\end{array}$ & $\begin{array}{c}\text { MEAN } \\
\text { (POST-OP) }\end{array}$ & $\begin{array}{c}\text { Std. } \\
\text { Deviation }\end{array}$ & Pvalue \\
\hline $\begin{array}{c}\text { CORONAL } \\
\text { THIRD }\end{array}$ & 15 & 1.7465 & 1.7567 & 0.19141 & 0.0005 \\
$\begin{array}{c}\text { Hand K-file } \\
\text { Kedo-S }\end{array}$ & 15 & 1.8678 & 2.0347 & 0.02850 & \\
$\begin{array}{c}\text { MIDDLE THRD } \\
\text { Hand K-file }\end{array}$ & 15 & 1.6389 & 1.6727 & 0.09169 & 0.0005 \\
$\quad$ Kedo-S & 15 & 1.6109 & 1.7527 & 0.13057 & \\
$\begin{array}{c}\text { APICAL THIRD } \\
\text { Hand K-file } \\
\text { Kedo-S }\end{array}$ & 15 & 0.4572 & 0.4960 & 0.09030 & 0.0005 \\
\hline & 15 & 0.6791 & 0.7393 & 0.15341 & \\
\hline
\end{tabular}

\section{DISCUSSION}

The principle objective of performing pulpectomy in an infected primary tooth is to retain it in the oral cavity until its physiological exfoliation to guide the erupting permanent teeth. [1] Effective cleaning and shaping of the root canal aids in removing the soft and hard tissue containing bacteria, necrotic debris and provides a path for optimal obturation for preserving the integrity of radicular structures. Thus, success of pulpectomy depends on complete elimination of the irritants from within the canals followed by optimal obturation of the disinfected canals, which can only be achieved by trenchant chemo-mechanical preparation of the primary root canals. [9]

However in primary teeth, the complex torturous anatomy of the root canals, 
presence of accessory canals, ramifications makes instrumentation more difficult in addition to the child's co-operation. [10] Conventional preparation of the canals using hand instrumentation can be incommodious resulting in zipping and elbows. [11] Also, the time taken for root canal preparation with the conventional hand file is higher resulting in clinician's fatigue and patient uncooperativeness. [12-14]

Introduction of exclusive pediatric Rotary instrumentation into pediatric endodontics has revolutionized the canal preparation step in pulpectomy of the primary teeth. [7] Use of Kedo-S rotary file in primary molars has shown a drastic increase in the quality of obturation and also decrease in the working time. [15] However, in the previous study recorded in the literature the quality of obturation was assessed using a two-dimensional radiographic method, which was the potential limitation mentioned. [15] The quality of obturation depends on the ability of the file used to clean and shape the canals. There are no studies in the literature that has evaluated the shaping ability of the Kedo-S rotary file. Hence in the present study the shaping ability of Kedo-S rotary file was assessed using a cone beam computerized tomography.

In the present study, it was noticed that with the use of rotary file the preparation of the coronal third was significantly greater with gradual taper in the middle and the apical third of the canal. This can be attributed to the design of the rotary file, which has a variable taper corresponding to the anatomy of the primary root canal. Also, it is noticed that with $\mathrm{K}$ files there is limited coronal preparation that can hinder an optimal obturation. In a previous study that evaluated the shaping ability of rotary and hand files in primary teeth, more conical preparation of the canals was observed with rotary files. [8] However, the rotary files used in the earlier study were those designed for use in permanent teeth.
The limitation of the present study is that only single rooted primary canine teeth have been used for assessment. Though Invitro studies have shown the Kedo-S pediatric rotary files are better than stainless-steel hand instruments, randomized clinical trials are required to assess clinical outcomes.

\section{CONCLUSION}

Kedo-S rotary files produces more conical and tapered canal preparation in primary teeth which is considered to be the ideal architecture for easy and optimal obturation.

\section{REFERENCES}

1. Fuks AB, Papagiannoulis L. Pulpotomy in primary teeth: review of the literature according to standardized assessment criteria. Eur Arch Paediatr Dent. 2006 Jun;7(2):64-71; discussion 72.

2. Guideline on Pulp Therapy for Primary and immature Permanent Teeth. Pediatr Dent. 2016 0ct;38(6):280-288.

3. Walton RE, Torabinejad M. Principles and Practice of Endodontics. 3 ed. Saunders Company; 2002: 222p.

4. Barr ES, Kleier DJ, Barr NV. Use of nickel-titanium rotary files for root canal preparation in primary teeth. Pediatr Dent. 2000 JanFeb;22(1):77-8.

5. Silva LA, Leonardo MR, Nelson-Filho P, Tanomaru JM. Comparison of rotary and manual instrumentation techniques on cleaning capacity and instrumentation time indeciduous molars. J Dent Child (Chic). 2004 Jan-Apr;71(1):45-7.

6. Govindaraju L, Jeevanandan G, Subramanian E. Knowledge and practice of rotary instrumentation in primary teeth among Indian dentists: a questionnaire survey. J Int Oral Health. 2017;9(2):45-8.

7. Jeevanandan G. Kedo-S Paediatric Rotary Files for Root Canal Preparation in Primary Teeth - Case Report. J Clin Diagn Res. 2017 Mar;11(3):ZR03-ZR05. doi: 10.7860/JCDR/2017/25856.9508. Epub 2017 Mar 1.

8. Musale PK. Rotary Instrumentation in Primary Teeth. J Int Oral Health. 2013 Apr;5(2):i.

9. Yang SF, Rivera EM, Walton RE, Baumgardner KR. Canal debridement: effectiveness of sodium hypochlorite and calcium hydroxide as medicaments. J Endod. 1996 0ct;22(10):521-5.

10. Fuks $A B$, Papagiannoulis L. Pulpotomy in primary teeth: review of the literature according to standardized assessment criteria. Eur Arch Paediatr Dent. 2006 Jun;7(2):64-71; discussion 72.

11. Hülsmann M, Schade MJ, Schäfers F. A comparative study of root canal preparation with HERO 642 and Quantec SC rotary NiTi instruments. Int Endod J. 2001 0ct;34(7):538-46. 
12. Govindaraju L, Jeevanandan G, Subramanian EM. Clinical evaluation of quality of obturation and instrumentation time using two modified rotary file systems with manual instrumentation in primary teeth. J Clin Diagn Res. 2017 Sep;11(9):ZC55-ZC58. doi: 10.7860/ JCDR/2017/30069.10602. Epub 2017 Sep 1.

13. Govindaraju L, Jeevanandan G, Subramanian EM. Comparison of quality of obturation and instrumentation time using hand files and two rotary file systems in primary molars: A single- blinded randomized controlled trial. Eur J Dent. 2017 Jul-Sep;11(3):376-379. doi: 10.4103/ejd.ejd 34516 .
14. Govindaraju L, Jeevanandan G, Subramanian EM. Application of rotary endodontics in pediatric dentistry - A review of literature. JPR 2018;12(4)

15. Jeevanandan G, Govindaraju L. Clinical comparison of Kedo-S paediatric rotary files vs manual instrumentation for root canal preparation in primary molars: a double blinded randomised clinical trial. Eur Arch Paediatr Dent. 2018;19(4):273-8. https://doi.org/10.1007/ s40368-018-0356-6

\section{Dr Lavanya Govindaraju}

(Corresponding address)

162, Poonamallee high road, Velappanchavadi,

Chennai, Tamil Nadu, 600077

Email-glaavuu@gmail.com 